Studia Judaica 23 (2020), nr 2 (46), s. 405-424

doi:10.4467/24500100STJ.20.020.13663

Monika Borzęcka

\title{
Kilka słów na marginesie Dziennika z getta Miriam Korber-Bercovici ${ }^{1}$
}

\author{
A FEW WORDS ON THE MARGIN OF THE DIARY \\ WRITTEN IN THE DJURIN GHETTO BY MIRIAM KORBER-BERCOVICI
}

\begin{abstract}
The purpose of the article is to present fragments of the diary of Miriam Korber-Bercovici, a young Jewish woman deported with her whole family from Southern Bukovina to the Transnistria Governorate under the Antonescu regime. The excerpts translated from the original Romanian into Polish mainly concern the author's experiences of deportation and everyday life in the Djurin ghetto. They were selected in order to acquaint Polish readers with the situation of the Jews of Bukovina and Bessarabia displaced to the Transnistria Governorate during World War II. The diary was first published in Romania in 1995 as Jurnal de ghetou. The presented translation is based on the second edition of the diary published in 2017 by Curtea Veche Publishing House and Elie Wiesel National Institute for Studying the Holocaust in Romania.
\end{abstract}

Keywords: Djurin ghetto, Transnistria Governorate, diary, Miriam KorberBercovici.

Słowa kluczowe: getto w Dżurynie, Transnistria, dziennik, Miriam KorberBercovici.

Podczas spotkania Rady Ministrów Rumunii w lipcu 1941 r. Mihai Antonescu, wicepremier i minister spraw zagranicznych tego państwa, powiedział, co następuje:

${ }^{1}$ Miriam Korber-Bercovici, Jurnal de ghetou, Editura: Curtea Veche, Institutul Național pentru Studierea Holocaustului din România „Elie Wiesel”, București, 2017. 
Jestem zwolennikiem przymusowego wysiedlenia całej społeczności żydowskiej z Besarabii i Bukowiny. Trzeba ją wyrzucić za granicę. Bądźcie dla nich bezlitośni. Nie wiem, ile wieków upłynie, zanim naród rumuński znów uzyska swobodę działania niezbędną do oczyszczenia etnicznego i zmiany narodowej... To czas, kiedy jesteśmy panami naszych terytoriów. Skorzystajmy z tego. Jeśli to konieczne, użyjcie karabinów maszynowych. Nie obchodzi mnie, czy przejdziemy do historii jako barbarzyńcy...2

Słowa te stanowiły początek jednego z mniej znanych rozdziałów historii zagłady Żydów europejskich. Deportacje ludności żydowskiej z Besarabii i Bukowiny rozpoczęły się na początku września tego samego roku. Ich celem stała się Transnistria - teren między Dniestrem a Bohem, kontrolowany przez III Rzeszę, oddany w zarząd Rumunii.

Dokładna liczba ofiar nie jest znana. Niektórzy zginęli jeszcze podczas deportacji - w trakcie wysiedleń, transportu w zatłoczonych wagonach bydlęcych, przeprawy przez Dniestr. Resztę rozlokowano w ponad stu miastach i wsiach na terytorium między Dniestrem a Bohem, gdzie umierali z głodu, zimna, wyczerpania i chorób. W zależności od źródeł szacuje się, że w wyniku tych działań na terenie Transnistrii zginęło od 280 tys. do 380 tys. Żydów.

Jedną z osób deportowanych do getta w Dżurynie była Miriam Korber, po mężu Bercovici. Urodziła się 11 września 1923 r. w Kimpulungu Mołdawskim, miejscowości położonej na południowej Bukowinie. Przed wojną była uczennicą liceum w Botoszanach. W 1940 r. została usunięta ze szkoły przez wprowadzenie ustaw antysemickich. Podczas II wojny światowej wraz z całą rodziną została deportowana na terytorium Transnistrii do getta w Dżurynie. W 1944 r. wróciła do Rumunii, gdzie ukończyła studia medyczne na uniwersytetach w Jassach i Bukareszcie. Specjalizowała się w pediatrii. Od 1959 r. do przejścia na emeryturę pracowała w bukareszteńskich szpitalach, instytucjach medycznych, wykładała na uczelni. W 1975 r. obroniła pracę doktorską z zakresu onkologii dziecięcej. Po przejściu na emeryturę przez trzynaście lat pracowała w gminie żydowskiej, a kolejne siedem - jako lekarka w żydowskim zespole szkół Lauder-Reut. Do dziś mieszka w Bukareszcie. W 1947 r. wyszła za Israela Bercovici, publicystę związanego z Teatrem Żydowskim w Bukareszcie i autora licznych publikacji poświęconych teatrowi jidysz.

Dziennik Miriam Korber-Bercovici jest jedynym znanym spisanym po rumuńsku świadectwem tych wydarzeń. Po raz pierwszy został

${ }^{2}$ Raport final, red. Elie Wiesel, Jassy 2005, s. 126. [tłum. Monika Borzęcka] 
opublikowany dopiero w latach dziewięćdziesiątych, z inicjatywy autorki. Jego oryginał przekazano do waszyngtońskiego United States Holocaust Memorial Museum. Podstawą prezentowanych tu fragmentów dziennika jest wydanie z 2017 r. opublikowane przez wydawnictwo Curtea Veche oraz Rumuński Narodowy Instytut Studiów nad Holokaustem im. Elie Wiesela, który udzielił zgody na niniejszą publikację. Wybór jest częścią przekładu całego Dziennika na język polski, umieszczonego jako aneks w pracy magisterskiej pt. Zapomniany Holokaust. Transnistria w dzienniku Miriam Korber-Bercovici: przekład i analiza ${ }^{3}$ autorstwa piszącej te słowa. Poniższe fragmenty dotyczą przede wszystkim doświadczeń Korber-Bercovici związanych z deportacją i codziennym życiem w getcie. Zostały wybrane w celu przybliżenia czytelnikowi sytuacji Żydów bukowińskich wysiedlonych na teren Transnistrii. Pominięto wątki poboczne, rozbudowane opisy przyrody i refleksje autorki, które nie wpływają na odbiór tekstu. W niniejszym wyborze uwzględniono niektóre przypisy z pierwodruku (zaznaczając to w odpowiednim miejscu), pomijając te, które objaśniają pojęcia znane polskiemu czytelnikowi. Pozostałe opracowała tłumaczka.

\section{Miriam Korber-Bercovici Dziennik z getta}

\section{Dżuryn ${ }^{4}$, Transnistria, 1941-1943 \\ Wtorek, 4 listopada 1941}

Kto by pomyślał, że w takich okolicznościach zacznę pisać w tym zeszycie, który miał być albumem na wierszyki. Kiedy Bondy ${ }^{5}$ mi go podarował, czasy były zupełnie inne. A teraz?! W czwartek miną cztery tygodnie od chwili, kiedy o dwudziestej pierwszej trzydzieści tato wrócił ze straszną wiadomością o wysiedleniach. Wtedy jeszcze nic nie było pewne. Dopiero w piątek wszyscy dowiedzieli się, że w niedzielę zostaniemy deportowani ${ }^{6}$. Tak zaczęła się gorączka wysiedleń. Płacz, szloch, pakowanie, załamania. Wszystko wrzało bez ładu i składu. Nie wiedzieliśmy, co nas czeka. To

${ }^{3}$ Praca powstała w Instytucie Judaistyki Uniwersytetu Jagiellońskiego w roku 2020 pod opieką prof. Magdaleny Ruty.

${ }^{4}$ Dżuryn (rum. Djurin) - wieś na Ukrainie w rejonie szarogrodzkim obwodu winnickiego.

${ }^{5}$ Przyjaciel Miriam.

64 października 1941 r. marszałek Antonescu podjął decyzję o deportacji Żydów bukowińskich za Dniestr. 9 października pierwsze transporty z deportowanymi wyruszyły do Otaci. Rodzina Miriam opuściła Kimpulung 12 października. 
sen - myśleliśmy - nie zdając sobie sprawy z tego, co stanie się później. W sobotę sklepy były zamknięte. Rozpoczął się nielegalny handel, rozdawanie rzeczy. Jak sępy zlecieli się chłopi, miastowi, sąsiedzi i obcy. Jednego poranka ogołocili domy z najpiękniejszych rzeczy. Po obiedzie, o trzeciej, rozeszła się plotka, że wszystko zostało odroczone na sześć miesięcy. Niepewność, niepokój. Wyjeżdżamy czy nie? Mamie i tacie było przykro z powodu tych sprzedanych i rozdanych rzeczy. Mnie też było ich żal, ale cały czas mieliśmy wątpliwości, czy pogłoski okażą się prawdą. Skończyliśmy pakowanie - jakbyśmy się wybierali na wycieczkę. Nie wyobrażaliśmy sobie, że można by było w ten sposób wyrwać nas z naszego domu. Wieczorem poszliśmy spać. Od tamtej pory nie spaliśmy w łóżku. W niedzielę o szóstej rano dowiedzieliśmy się, że wyjeżdżamy. Zaczęliśmy zdawać sobie sprawę z koszmaru sytuacji, w której się znaleźliśmy. Nie wiedzieliśmy wtedy, co nas jeszcze czeka. Kto mógłby mieć aż tak czarne myśli? O jedenastej rano wozy zaczęły zatrzymywać się na dworcu na końcu wioski. Taki był początek naszej tułaczki. Długa, błotnista droga zatłoczona wozami, pełna worków, tobołów, dzieci i starców. Na ziemi obok wozów młodzież. Cyganie lepiej to znoszą. Oni mają wozy, my nie mamy nawet tego. Zostawiliśmy w tyle Kimpulung i dotarliśmy na dworzec. Tam było jeszcze straszniej. Płacze, szlochy, bagaże, krzyki, ładowanie ludzi do wagonów przeznaczonych do transportu koni. Wagony zostały oczyszczone ze słomy i wsiedliśmy my. Do jednego - 38 osób. Wśród nas czworo starszych ludzi, mniej więcej osiemdziesięcioletnich, i jedno sparaliżowane dziecko. Baliśmy się, żeby nie zaplombowali wagonu. $\mathrm{Na}$ dworcu ludzie dzielili się chlebem. Zgodnie z naszymi wyobrażeniami i tym, co mówiono, jechaliśmy do miejscowości w głębi Besarabii - Otaci Krążyły pogłoski, że zostaniemy tam zakwaterowani i dostaniemy środki do życia. O ósmej wieczorem wyjechaliśmy razem z drugim transportem. Pierwszej nocy wydawało nam się, że wybraliśmy się na wycieczkę. Nie zdawaliśmy sobie sprawy z tragizmu naszej sytuacji. Spaliśmy na bagażach. $\mathrm{W}$ poniedziałek w pociągu jedliśmy stare mięso, piliśmy brudną wodę, ale wciąż się śmialiśmy i kłóciliśmy ze starszymi. Budowaliśmy zamki na piasku, mieliśmy nadzieję, że dostaniemy jedzenie, że będziemy pracować, uczyć się pracy na roli. Przejechaliśmy przez Czerniowce i naszym oczom ukazał się prawdziwy step. Jak wielki jest step i jak nieskończone jest niebo nad stepem!

${ }^{7}$ Otaci (rum. Otaci) - miasto w północnej Mołdawii na prawym brzegu Dniestru. Było jednym z przejść między Rumunią a Transnistrią. 
Mimo rozlegających się wokół lamentów dostrzegłam cudowny zachód słońca. We wtorek rano dotarliśmy do Otaci. Do szóstej wieczorem staliśmy na zewnątrz, a potem wozem udaliśmy się do miasta. „Dalej, Żydzie!” Na drodze były tysiące ludzi. Setki w domach, ale jakich domach! Wszystkie zniszczone, bez dachów, drzwi i okien. Domy zamordowanych Żydów. Na każdej ścianie wypisane były węglem imiona zabitych. Razem z aptekarzem Garaiem ${ }^{8}$ naliczyliśmy trzydzieści w każdym pokoju. To była najstraszniejsza noc...

\section{Piątek, 7 listopada 1941}

Dopiero dziś od nowa zaczynam relacjonować potworności, przez które przeszliśmy. Kto wie, czy nie czeka nas coś jeszcze gorszego. Pierwszej nocy w Otaci zobaczyłam, czym jest nędza człowiecza. Widziałam ludzi pozbawionych ludzkiej twarzy, dzieci z opuchniętymi oczami, odmrożone nogi, bezsilne rączki. Widziałam matki z martwymi dziećmi w ramionach, starców, młodych zawiniętych w łachmany. Byli to Żydzi z obozu w Jedyńcach $^{9}$. Wypędzeni, zarażeni tyfusem, zawszeni, umierający z głodu. [...]

\section{Sobota, 8 listopada 1941}

W Mohylowie ${ }^{10}$ zdaliśmy sobie sprawę z tego, że już nie jesteśmy w Rumunii. Wszyscy mówili po ukraińsku, a między żołnierzami rumuńskimi krążyli ukraińscy milicjanci. Kiedy przyjechaliśmy, zaczęło się przepędzanie. Istnieją obozy, w których ludzie są gromadzeni setkami, i stamtąd wypędzani dalej, pieszo. Obozów zatem powinniśmy się wystrzegać. $Z$ trudem nieśliśmy bagaże znad Dniestru i przez dwie godziny drżeliśmy z zimna, aż znaleźliśmy schronienie. $Z$ trzydziestoma innymi osobami zgromadziliśmy się w izbie na parterze, całkiem przestronnej. $Z$ nami były inne rodziny - Hausvaterowie, Horovitzowie, Hellerowie, Segalowie, Javetzowie, Tatarowie. Ciekawa grupa! Wnieśliśmy bagaże nieżywi ze zmęczenia i przespaliśmy pierwszą noc w Mohylowie. [...]

8 „Z Kimpulungu deportowano wszystkich, poza jednym z dwóch aptekarzy [...]. Ten deportowany, Garai, zwariował. Był węgierskim Żydem z wyraźnym akcentem. W kółko powtarzał, że jest wzorowym obywatelem, zawsze płacił podatki, nie rozumiał, jakim prawem wyrzucono go z jego własnego domu”, Cosmina Guşu, Interviu Miriam Korber-Bercovici, http://www.inshr-ew.ro/ro/marturii/162-interviu-miriam-korber-bercovici.html [dostęp: 1 maja 2020].

9 Jedyńce (rum. Edineț) - miasto w północnej Mołdawii. W 1941 r. utworzono tam obóz przejściowy dla deportowanych Żydów.

${ }_{10}$ Mohylów Podolski (rum. Moghilău) - miasto na Ukrainie przy granicy z Mołdawią, nad Dniestrem. W 1941 r. utworzono w nim jedno z gett. 
Mieszkamy niedaleko Dniestru, więc codziennie widzimy, jak ludzie przechodzą przez rzekę. Są bici, pędzeni, ograbiani. Muszą przechodzić nocą. Krzyki, wrzaski, lamenty, płacze matek, zgubione dzieci. To wszystko zasmuca nas jeszcze bardziej. Pośród tego wszystkiego panikę wzbudzają strzały na oślep oddawane przez żołnierzy. Tak noce dopełniają dni przesiąknięte żalem i strachem, że żołnierze zaprowadzą nas do obozu.

Ze wstydem muszę się przyznać, że tańczyłam w Mohylowie. Śmiałam zapomnieć na moment o naszym nieszczęściu. Szybko zostałam za to ukarana. O ósmej wieczorem przyszli ludzie z Radowiec z muzyką Bubiego Hellera. Kiedy tańczyliśmy, przyszło trzech żołnierzy. Jedynie dzięki dużej łapówce zostawili nas w spokoju. W tej sytuacji przestraszyliśmy się jeszcze bardziej. Tamto „psst, psst” pamiętam do dziś. Decyzja o naszym wyjeździe z Mohylowa podjęta została szybko. Bondy zdołał wejść w kontakty z Niemcami, którzy za pieniądze wywozili wagonami Żydów w głąb terytorium Transnistrii. W ten sposób opuściliśmy Mohylów. Zapomniałam wspomnieć, że spotkałam Malca, chłopaka, którego znałam jeszcze z Botoszan ${ }^{11}$. Prawie go nie poznałam. Kiedy się znaliśmy, czasy były inne. W sobotę rano wyruszyliśmy niemiecką ciężarówką w kierunku Dżuryna.

\section{Niedziela, 9 listopada 1941}

W deszczowy sobotni poranek dotarliśmy do Dżuryna. Niemcy zostawili nas na skrzyżowaniu znajdującym się daleko od wsi. Ukraińcy przyszli nas oglądać, jakbyśmy byli jakąś atrakcją. Wieś wydała nam się bardzo piękna, choć niesamowicie zabłocona. Na początku mieszkaliśmy u nauczycielki. Była sympatyczna, ale próbowała wzbogacić się naszym kosztem. Od soboty do środy mieszkaliśmy w jednym pokoju razem z trzynastoma osobami. Cały czas spałam na podłodze. Warunki były więc trudne. [...] Widząc, że nauczycielka nie śpieszy się, żeby nam pomóc, tylko nas wykorzystuje, i że nie mamy co liczyć na łóżko do spania czy miejsce przy stole, mama zaczęła szukać nam pokoju. Zanim go jednak znalazła, mieliśmy okazję umyć się porządnie. Nigdy nie myślałam, że może to sprawić tyle przyjemności. Znowu zaczął się problem z jedzeniem. Wiedzieliśmy, że powinniśmy je racjonować, żeby za parę miesięcy nie umrzeć z głodu. Przez pierwsze dni nie wychodziliśmy z domu. Cały czas padało, wszędzie było błoto. Tutaj również nie ma toalet. W środę mama znalazła pokój. Ach! Jaki pokój! Dom stał na wysokim, błotnistym wzgórzu. Przypominał kurnik. Przez nasz

${ }^{11}$ Botoszany (rum. Botoșani) - miasto w północnej części historycznej Mołdawii w Rumunii, skąd pochodzą dziadkowie Miriam. 
pokój ciągle ktoś przechodził, a błoto było wszędzie. Na drodze, w pokoju, w domu. Mieszkamy w izbie razem z rodziną Apelów. W innej mieszka Rosjanka, która nazywa się Kufsinier, Żydówka, bardzo interesująca, mogłaby być aktorką w teatrze żydowskim. Biedna, ma dwójkę małych dzieci, jej mąż jest w wojsku, a ona straciła wszystko. Mimo to wciąż ma nadzieję. Czy my także jeszcze ją mamy? Tak mijają dni. [...]

\section{Piątek, 26 grudnia 1941}

Wczoraj był pierwszy dzień świąt Bożego Narodzenia. Nie wiem dlaczego, ale wstałam podekscytowana. Była cudowna pogoda, słońce, błyszczący śnieg, mróz. Tylko gdzie jest Boże Narodzenie sprzed roku, sprzed dwóch lat? Gdzie są Botoszany? Gdzie jesteśmy my? Czy nasi bliscy w ogóle o nas myślą? Przypuszczam, że ronią łzy nad naszym nieszczęściem! Czy uda nam się to przetrwać? To jest pytanie, które stawiamy sobie każdego dnia. Czy będziemy mieć tyle siły, żeby przez to przejść? Jemy, co tylko da się zjeść, a jednak wszyscy wyglądają źle. Dziś w nocy zaczął wiać północno-wschodni wiatr. Prawdziwy, ukraiński, stepowy wiatr. Wieje też w naszej izbie. Na wzgórzu podmuchy są tak silne, że ma się wrażenie, iż dom odfrunie. Jest bardzo zimno. Ludzie mówią, że może być jeszcze zimniej - śnieg może zatarasować drogi, a woda zamarznać w pompie. Dzisiaj rano poszłyśmy z Sisi po wodę. Wróciłam, płacząc. $\mathrm{Z}$ zimna zdrętwiała mi prawa ręka, zdawało się, że zaciska się też serce. Po drodze upadłam trzy razy. Do tego wszystkiego Bondy znowu wyruszył do Morachwi ${ }^{12}$. Biedak, szedł tylko po to, żeby zarobić kilka rubli. Takie czasy nastały. Tato jest zdenerwowany. Mama też. Nie zarabiają, a pieniądze znikają. Musimy przecież jeść. Jesteśmy przyzwyczajeni, że jadamy odrobinkę lepiej niż inni. Tata nie może się pogodzić z „lenistwem”, czyli z tym, że nie ma stałego zajęcia. Nagromadzoną energię zużywa na kłótnie z nami. Dogryzamy sobie wzajemnie jedynie przez brak obowiązków. Jest druga po południu. W izbie jest zimno. Nie wiem, jak przetrwamy noc bez ognia. Drewno jest bardzo drogie. Na wszystkich twarzach odczytuję strach przed jutrem. Co się wydarzy? Z czego będziemy żyć? Kiedy skończą się pieniądze? Słyszy się dobre wiadomości z frontu. Być może zbliża się ratunek.

\footnotetext{
${ }^{12}$ Morachwa - wieś na Ukrainie w rejonie szarogrodzkim obwodu winnickiego, gdzie funkcjonowało jedno z gett Transnistrii.
} 


\section{Czwartek, 1 stycznia 1942}

Dziś zaczął się nowy rok! Wczoraj wieczorem, w sylwestra, położyliśmy się już o wpół do ósmej. Tak zimno było w izbie. Jest straszny mróz. Jeśli to się utrzyma, nie wiem, jak przeżyjemy zimę. Przez kilka ostatnich dni ani razu nie mogłam ogrzać nóg. Po ścianach leje się woda, na oknach i okiennicach jest centymetrowa warstwa lodu. Tak zaczął się nowy rok. Myślę o tym, jak wspaniale było w domu. Nie wspominając już nawet o zabawach. Chciałabym tylko ogrzać się porządnie. [...] Jak tę noc przeżyłam, tylko Bóg jeden wie. Było tak zimno, że nie mogliśmy nawet wyściubić nosa spod kołdry. Dziś, pierwszego stycznia, w zimnie i wilgoci, siedzę i myślę, do kogo mogłabym pójść, żeby zagrzać się chociaż trochę. W domu zima nie była problemem. Przyjemnie było chodzić w śniegu, by po powrocie zastać rozpalony piec i ciepłą izbę. Tutaj, ubrana jak Baba Dochia $^{13}$, oddechem ogrzewając dłonie, nie mogę znieść myśli o wyjściu na zewnątrz. Teraz spotkało nas następne „szczęście”. Właścicielka, która do zeszłego tygodnia była przyzwoita, pokazała pazurki. Umawialiśmy się, że będziemy jej płacić pięćdziesiąt rubli na miesiąc. Teraz już nie chce pieniędzy i prosi o pół puda mąki. Tylko Bóg i my wiemy, że nie jesteśmy w stanie jej tego dać, bo oszczędzamy każdy kawałek chleba i każdą łyżkę zupy. Żebyśmy tylko mogli to wszystko kiedyś opowiedzieć. [...]

\section{Sobota, 3 stycznia 1942}

Minus trzydzieści osiem stopni Celsjusza. Niemożliwym jest wyjście na zewnątrz, a i w domu jest tak zimno, że musimy siedzieć w płaszczach. Wczoraj wieczorem nawet zupę rozlewałam tak opatulona. Bardzo niska temperatura powodowała mgłę, przez którą nie było nic widać. Do tego nerwowe wybuchy ojca, które jeszcze pogarszają sytuację. Jest w takim stanie, że zaczęłam obawiać się najgorszego. Biedna mama jest męczennicą. Rozpieszcza go jak małe dziecko i z anielską cierpliwością znosi wybuchy złości. A wścieka się o każdą drobnostkę, aż do czerwoności. Nie dość, że sam sobie szkodzi, to także nas dręczy. Dlatego musimy ważyć każde słowo. Jeśli uspokoiłby się trochę, byłoby o wiele lepiej. Dogadaliśmy się z właścicielką. Płacimy jej sto dwadzieścia rubli na miesiąc. Tak, pieniądz może wszystko.

Gdybym tylko mogła zapomnieć o tym, co było! Jest trudniej, kiedy pamięta się inne czasy - dom, w którym było ciepło i nie brakowało

\footnotetext{
13 Baba Dochia - postać z rumuńskiego folkloru wiązana z powrotem wiosny.
} 
jedzenia. Nie tylko jestem głodna. Tęsknię za czymś dobrym. Zjadłabym ciastko albo coś tłustego. Jeśli mielibyśmy tłuste jedzenie albo trochę masła, byłoby łatwiej. Same ziemniaki, fasola i mamałyga... Zaspokajamy głód, ale tęsknimy za jedzeniem tak samo jak za światem. Tata dostał ukraińską czapkę. Jest mu w niej do twarzy. Tak, wtapiamy się. Człowiek jest zwierzęciem, wszystko jest kwestią przyzwyczajenia. Możemy przyzwyczaić się do złego, ale i tak pamiętamy czasy, kiedy było dobrze. To boli najbardziej ze wszystkiego! [...]

\section{Środa, 21 stycznia 1942}

Dziś mija rok od rebelii ${ }^{14}$. Wtedy już było tak źle, że nie myśleliśmy, iż może być gorzej. Dziś myślę, że byłoby lepiej, gdyby nas wszystkich wtedy zamordowali. U nas w domu. Po co było wysyłać nas do tej dziczy, gdzie umieramy z zimna i głodu? Śmierć w domu byłaby bardziej ludzka. A tutaj? Miotamy się w spazmach. Nie minutę, jak skazańcy pod murem, ale tygodnie, lata, Bóg wie ile! Dnie i noce mijają szybko. Czternastogodzinne noce, bo tyle zwykle spędzamy w łóżkach. Żeby chociaż nie było mrozu! Jest przerażająco zimno, do szpiku kości, stepowy wiatr kąsa z porywczością nieznaną nam, pochodzącym z gór. Zawsze jedno i to samo zmartwienie. Co dziś zjemy? Co będziemy jeść jutro? [...]

\section{Poniedziałek, 26 stycznia 1942}

Ten dzień wymyka się wszelkim opisom, jest niemożliwy do pojęcia przez ludzki umysł. Realny byłby jedynie uchwycony w filmie, i to mało autentycznym. Nie mówię już nawet o zimnie, bo w tygodniu temperatury wahały się między minus trzydziestoma a minus trzydziestoma pięcioma stopniami Celsjusza. Dziś w nocy wiatr wiał z coraz to większą siłą. Rano pierwsza wyszłam z domu załatwić się i nie wiedziałam, jak wrócić. Wiatr, śnieg, zamieć i zawierucha, która przypomina mi sceny z filmu Huragan ${ }^{15}$. Ukraina. To słowo rozumiem dziś w zupełnie inny sposób. Składa się na nie zimno, okrutny wiatr, głód, cały ten brud, w którym żyjemy i pogrążamy się. Dziś to wszystko osiągnęło apogeum. Jakaś dziewczyna, która w domu ewidentnie nigdy sama nie dźwigała wody, przemierza wzgórze z dwoma pełnymi wiadrami, a wiatr wieje tak mocno, że nie może oddychać. Jakiśs

\footnotetext{
${ }^{14}$ Między 21 a 23 stycznia 1941 r. w Rumunii doszło do nieudanej próby zamachu stanu dokonanej przez faszystowską Żelazną Gwardię. Reperkusją tych wydarzeń były mordowania ludności żydowskiej i pogrom w Bukareszcie.

${ }^{15}$ Huragan - amerykański film z 1937 r. w reżyserii Johna Forda i Stuarta Heislera.
} 
chłopak i jego stary ojciec niosą na plecach kawałek drewna, jeszcze ktoś ciągnie gałąź czy worek z ziemniakami. Wszyscy chcą żyć, a wiatr, nieważne jak mocny, nie jest w stanie osłabić w nich woli życia. Dlaczego właściwie chcemy żyć? Na nogach trzyma nas jedynie nadzieja. Kiedyś nie byłabym w stanie sobie wyobrazić, że na trzydziestostopniowym mrozie mogłabym przetrwać w nieogrzewanej izbie częściowo pozbawionej sufitu. A jednak żyjemy. I czekamy. [...]

\section{Środa, 28 stycznia 1942}

Wiatr, śnieg, zamieć, mróz. Od przedwczoraj ani na chwilę nie przestało wiać, a śnieg więzi nas w domu. Rano wyszłam po wodę. Myślę, że w tej sytuacji piekło jest konceptem zbędnym, bo kto przechodzi przez to, przez co my teraz przechodzimy, z założenia powinien być oczyszczony z grzechu. Drogi nie ma, trzeba ją sobie samemu utorować, jeśli chce się przejść. Nogi całe mokre. Rondelkiem napełniam wiadro $\mathrm{z}$ wodą. $\mathrm{W}$ ten sposób dotarłam z pełnymi wiadrami aż na szczyt wzgórza. W domu wybuchłam płaczem. Z zimna i ze strachu, bo palce zmarzły mi do tego stopnia, że nie mogłam nimi w ogóle ruszać. Nie mogę nic powiedzieć. Muszę milczeć. Są tu tacy, którzy nie mają w co się ubrać, a muszą wychodzić na zewnątrz. Dlaczego tak tęsknimy za życiem? Czemu nie skrócimy tej udręki? Tchórzostwo czy duma każe nam przezwyciężać trudności? Czy kiedyś je w końcu pokonamy? Być może po tym wszystkim staniemy się znowu ludźmi i w innych czasach będziemy doceniać to, co dobre.

Moje myśli nie płyną w normalny sposób. Przelatują od jednej do drugiej, nie mogę ich zatrzymać, myślę o zbyt wielu rzeczach. Ludzie umierają setkami, umierają też ci najbardziej wartościowi. Zmarł pan Wassermann. Pamiętam go, jak chodził z laską w dłoni, w słomkowym kapeluszu, taki spokojny. „Szalom”, pozdrawialiśmy go, a jego spokojna odpowiedź przypominała pozdrowienie z innego kraju. Był syjonistą, a jego wiara w Palestynę była tak silna, że Opatrzność powinna tak pokierować jego losem, żeby zakończył życie tam, gdzie chciał to zrobić. A jednak umarł tu, w Mohylowie, daleko od swoich zmarłych, daleko od tych żywych, którym oddałby nawet swoje ostatnie tchnienie. Zmarł też przewodniczący Gminy Wyznaniowej z Gury Humorului ${ }^{16}$. Uśmiercił go tyfus. W Mohylowie panuje straszna epidemia. [...] winie.

${ }^{16}$ Gura Humorului - miejscowość w północnej Rumunii, w okręgu Suczawa, w Buko- 


\section{Czwartek, 29 stycznia 1942}

Wczorajszego wieczoru nie zapomnę nigdy. Wszystko było w porządku, tato relatywnie dobrze usposobiony. Położyłyśmy się z Sisi. Tato jeszcze raz wyszedł na zewnątrz i wracając, zgasił niechcący lampę Horovitza, który mieszka w przedpokoju. Zdarza się to często przez przeciąg. Tyle wystarczyło, żeby tato, okropnie zdenerwowany, zaczął krzyczeć, póki mama, z trudem, go nie uspokoiła. Całą noc szlochał i żałował tej śmiesznej sceny. Było mu smutno i zdawał sobie sprawę z tego, że postawił nas w bardzo głupiej sytuacji. Biedny, ma usprawiedliwienie. Mam wrażenie, że popadł w zupełną neurastenię. Całe życie pracował i teraz widzi, że z tego wszystkiego zostało mu jedynie zawiniątko z paroma łachmanami. To mniej niż posiada Cygan. Współczuję tacie, ale mamy tak bardzo mi szkoda, że nie daję rady. Każdy grymas taty, każde słowo, każdy ruch w nocy musi znosić spokojnie i z anielską cierpliwością. Wstyd mi i ciężko na myśl o tym, co się dzieje. Łzy to za mało, żeby wyrazić to, co czuję. W domu tato był człowiekiem bez skazy, a tutaj musimy obchodzić się z nim, jakby był chory. Faktycznie, jest chory. Jeśli nie zostaniemy uratowani, nie wiem, czy kiedykolwiek wróci do zdrowia. [...]

\section{Środa, 10 lutego 1942}

Jest już luty. Pogoda się poprawiła. Od paru dni nie dokucza nam mróz. Chociaż tak natura nagradza za cały ten czas. Mimo zmiany pogody nie zmniejszają się nasze problemy. Każdego dnia inne zmartwienia, inna wiadomość, która wytrąca z równowagi. Zbliża się ocalenie, zbliża ucieczka, później oddala, wszystko jest tylko złudzeniem, którego pragniemy, i - jak każde złudzenie - znika z końcem mijającego dnia. Fatamorgana naszego życia: dom. Dużo się mówi o tym, że już wkrótce zostaniemy ułaskawieni. Za jakie przewinienia? Nie wiemy. Pewnie po prostu wybaczone nam zostanie, że jesteśmy Żydami. Potem wszystko przemienia się w dym i żal. Nawet teraz czuję tęsknotę za ojczyzną. Nigdy nie uważałam Rumunii, a raczej Kimpulungu, za prawdziwą ojczyznę. Zawsze byliśmy uciśnieni i spychani w kąt przez Rumunów. Dziś jednak, kiedy jesteśmy daleko, sto kilometrów od naszego małego Kimpulungu, tęsknię i czuję, jak bliska mi jest ta ojczyzna. Heimat ${ }^{17}$, jak często wypowiadam to słowo? Nasze góry, ukochane góry, gdzie jesteście? Dlaczego prześladujecie mnie nawet w snach? Jodły, ciemne lasy, czyste domy, piękni ludzie. Ojczyzno, tęsknię

\footnotetext{
${ }^{17}$ Heimat (niem.) - ojczyzna. [przyp. oryginalny]
} 
za Tobą! Dlaczego jesteśmy tak grzeszni, że nie mamy ojczyzny, która by nas kochała? Nasza wygnała nas na to pustkowie, między nieznajomych i między słowa, które wiecznie mnie prześladują: „dalej, dalej, Żydzie wieczny tułaczu". [...]

\section{Poniedziałek, 16 lutego 1942}

Zmarli dziadkowie. W Mohylowie, jedno po drugim. Dziadek zmarł trzeciego stycznia, a babcia cztery tygodnie później. W sobotę otrzymaliśmy smutne wieści. Mama przeczytała list i z jej twarzy wyczytałam wszystko. Tata, biedny, zniósł to lepiej, niż bym przypuszczała. Ciężki cios przyniosło mu przeznaczenie. W milczeniu płakał i w milczeniu znosił ból. On, jedyny syn, spełnia obowiązek i odmawia kadisz codziennie. Ja także łkałam i serce mi się skurczyło na myśl o tym, jak wyglądała ich smutna śmierć. Nie płakałam dlatego, że zmarli, bo śmierć jest pisana każdemu - a oni żyli pełnią życia i mieli ponad osiemdziesiąt lat - tylko dlatego, że umarli w Mohylowie, daleko od domu, od ich czystego łóżka, kilkudziesięcioletniej pracy, wszystkiego, co odebrał im los. Zmarli w ciszy. Tak, jak żyli. [...]

\section{Piątek, 27 marca 1942}

Wiosna odniosła zwycięstwo. Trzy dni temu słońce przebiło powłokę chmur i świeci z odnowioną mocą. Jest ciepło, wiatr lekko powiewa, jest wiosna... Siedzę w łóżku i piszę. Jest ósma rano. Zostało sześć dni do Pesach ${ }^{18} \mathrm{i}$ wszyscy wciąż tu jesteśmy! Smutne jest to, że teraz modlimy się o to, aby tu pozostać! Raz mówi się, że zostaniemy przesiedleni za Boh, innym razem, że do jakiegoś obozu w Besarabii, a to oznaczałoby pewną śmierć. Pesach spędzamy w Dżurynie. W zeszłym roku taki scenariusz nawet nie przyszedłby mi do głowy, ale jednak to prawda. Musimy pobielić ściany, posprzątać. Kiedy patrzę na mamę, mam ochotę krzyczeć z bólu. Pamiętam, co robiła w domu przed Pesach. Nawet nie ma takiej potrzeby, żeby pisać, że pamiętam. Wszystko było takie czyste, uporządkowane. Teraz, sześć dni przed Pesach, nic jeszcze nie zrobiliśmy. Na szczęście jeszcze jest czas, żebyśmy skończyli sprzątać naszą „sypialnię”, „salon”, „kuchnię”, „drewnianą spiżarnię” i „garderobę”, bo wszystko to mieści się w jednej izbie. Nie naszej, ale współdzielonej z innymi. Jutro wieczorem

${ }^{18}$ Pesach - najważniejsze i najstarsze święto żydowskie cyklu rocznego obchodzone na pamiątkę wyzwolenia Izraelitów z niewoli egipskiej. 
mamy nadzieję zacząć piec przaśny chleb ${ }^{19}$. Czytałam w książkach, że tutaj piecze się go samodzielnie. Co prawda słyszałam, że jest gdzieś piec chlebowy, ale my zrobimy go bez niego. Na zewnątrz rozpoczyna się cud wiosny. Strumyki spływają doliną i oczyszczają przestrzeń z jesiennego i zimowego brudu. Niestety, tutaj wiosna nie wprawia mnie w dobry humor tak, jak było w domu. Co mnie jeszcze czeka? Tyfus? Nie mogę więcej myśleć o domu. Muszę przyzwyczaić się do myśli, że być może nie będę miała już domu i zawsze będziemy się tułać jak nomadzi. Być może tak byłoby prościej. Żałuję, że wspomnienia są silniejsze niż chęci, żeby je porzucić. Napływają jedno za drugim, obracają się jak w błędnym kole. Dzieciństwo, przeszłość, smutna teraźniejszość, niepewna przyszłość. Jest wiosna, ptaki ćwierkają, słońce świeci, a serce?! Serce rozpacza!

\section{Poniedziałek, 1 kwietnia 1942}

Miałam wiele do zanotowania, ale codziennie coś przeszkadzało mi w pisaniu. W sobotę wieczorem, dwudziestego ósmego marca, sami piekliśmy chleb przaśny, wszystkie rodziny razem, ale w piekarniku w naszym domu. Nie zapomnimy, jak ciekawa była ta noc. Musieliśmy robić to w nocy, bo zabronione było pieczenie chleba przaśnego samodzielnie. [...]

Pierwsze dwa dni Pesach były bardzo smutne. Wszyscy przygnębieni, każdy wspominał coś, co zostawił w domu. Oczywiście głównym tematem był ten najczęściej poruszany tutaj: jedzenie. Myślę, że jedzenie jest tym, czego najbardziej pragnie człowiek, który nie ma niczego innego. My nie mamy czego chcieć, więc chcemy tego, czego nie mamy. [...]

Patrzę na zdjęcia, przeraża mnie wspomnienie czasów, kiedy byłam szczęśliwa, mimo że nie wiedziałam, że jestem. Takie jest szczęście - ulotne. Przypomina mi się wers z Heinego: Das Glück ist eine leichte Dirne ${ }^{20}$.. . Nas, Żydów, szczęście opuściło. Kiedy ktoś mówi mi pokrzepiające kłamstwo, prawie nigdy nie wierzę w nie. Każdego dnia czuję, jak ubywa mi odwagi. Pozostaje jedynie żal za tym, co było, za czasem, którego nie wykorzystałam w pełni tak, jak zrobiłabym to teraz. Nić została zerwana i nie wiem, czy umiałabym powrócić do tego, co zostawiłam.

${ }^{19} \mathrm{~W}$ języku rumuńskim istnieją dwa określenia oznaczające żydowską macę - mața oraz pasca evreiască. Autorka używa słowa azima, które również tłumaczone jest jako 'chleb przaśny', a także - 'opłatek'.

${ }^{20}$ W tłumaczeniu z języka niemieckiego: „Szczęście jest jak lekkomyślna dziewczyna”. [przyp. oryginalny] 


\section{Sobota, 18 kwietnia 1942}

Minął tydzień. Jeśli chciałabym pisać codziennie, miałabym o czym, bo nie ma dnia bez nerwów i smutku. Teraz jednak wszystko się uspokoiło, jest monotonnie, zbyt monotonnie. Codziennie nadzieja, że wrócimy do domu, codziennie drażniące kłamstwa, bo przecież dobrze wiem, że to wszystko nieprawda. Za każdym razem, kiedy mam wątpliwości - rzeczywistość szybko je weryfikuje. Dziś znowu jest piękny, wiosenny dzień. Cały tydzień padało, wiatr był nieznośny. Przedwczoraj, po sześciu miesiącach odkąd wyjechaliśmy z domu, mogłam się wykąpać. Było mi bardzo przyjemnie, przypomniałam sobie ostatnią kąpiel w domu. Czego bym nie dała, żeby przeżyć ją raz jeszcze.

To dziwne, dzisiejsza piękna pogoda mnie zasmuca.

\section{Sobota, 2 maja 1942}

Czytam ostatnie linijki tego, co napisałam poprzednio i śmieję się. Śmieję, bo w Dżurynie wiosna nie jest wiosną, słońce nie jest słońcem, a zieleń zielenią. Już zapomniałam o tych kilku pięknych dniach, bo po nich nastąpiły inne, liczniejsze, brzydkie dni. Wietrzne, pełne deszczu i błota. [...]

Kiedy widzę żebraka, robi mi się zimno. Wydaje mi się, że patrzę na siebie za rok, dwa. Co będzie? Jaki będzie nasz koniec? Były dni, kiedy myślałam i miałam nadzieję, że nasz los się poprawi, że ktoś się nad nami zlituje, ale nie mam już nadziei. To jasne, że do końca wojny zostaniemy tutaj. Kiedy i jaki będzie ten koniec? Na to pytanie nikt nie potrafi odpowiedzieć. Wczoraj czytałam dobrą książkę, naprawdę dobrą, nie tylko jak na Dżuryn. Amok Stefana Zweiga. Czego bym nie dała, żeby móc czytać ją w domu, na kanapie, przy świetle elektrycznym, nie przy kaganku, na twardym łóżku i słomianym materacu. Muszę jednak milczeć, bo są inni, którzy mają dziesięć razy gorzej, którzy nie mają gdzie się położyć, umierają wśród obcych. Cóż będzie, jeśli faktycznie kiedyś będziemy mogli wrócić do domu? Czy wróci chociaż połowa z tych, którzy przyjechali? Tyfus i głód sieją spustoszenie wśród deportowanych. Nadano nam zbiorową nazwę kolonii żydowskiej z Transnistrii. Tak, jesteśmy kolonistami bez ziemi, bez domów. Kolonizujemy powietrze, rzuceni jesteśmy na pastwę głodu i chorób. [...] 


\section{Sobota, 13 czerwca 1942}

Minął prawie miesiąc, odkąd pisałam w dzienniku. Tak wiele się wydarzyło! Sprawy tragiczne, komiczne, bolesne, przyjemne i nieprzyjemne. Nie pisałam nie dlatego, że nie miałam o czym, ale dlatego, że nie miałam cierpliwości, żeby zacząć. Już wolę raczej siedzieć i nie robić nic, patrzeć na sufit, na podłogę, na dom i nudzić się, byle nie trzymać ołówka w ręce. [...] We wtorek minęły trzy tygodnie, odkąd tato zachorował. Jego choroba bardzo mnie przeraziła. Wcześniej tylko bolała go głowa, a później dostał wysokiej gorączki, trzydzieści dziewięć stopni. Od początku podejrzewałam, że może to być tyfus. Niestety, nie pomyliłam się. Od środy do niedzieli tato siedział chory w domu. My, wtajemniczeni przez lekarza, dowiedzieliśmy się szybko, na co jest chory. W niedzielę został przetransportowany do szpitala chorób zakaźnych urządzonego przez nas, deportowanych. [...] Kiedy widziałam, jak wynoszą tatę na noszach, łzy napłynęły mi do oczu, a ponieważ człowiek jest swoim najgorszym wrogiem, od razu pojawiły mi się w głowie najczarniejsze myśli. Mijające dni, aż do przedwczoraj, były smutne i pełne zmartwień: wchodziłam na wzgórze i schodziłam z niego dziesięć razy dziennie, o pieniądzach nawet nie wspominam! Zastrzyki z kamfory i kofeiny, lekarz, dyżurny, pieniądze i jeszcze raz pieniądze, ale też strach, obawa przed katastrofą. Tato był bardzo słaby, ale, dzięki Bogu, od trzech dni nie ma już gorączki i myślę, że nie grozi mu już bezpośrednie niebezpieczeństwo, ale było ciężko. I dla niego, i dla nas. Jest wciąż wycieńczony chorobą, ale pod dobrą opieką wróci do formy. Nawet mu trochę zazdroszczę, że wyzdrowiał, a teraz, uodporniony, może przemierzać miasto bez strachu. W każdym razie bardzo bym chciała, żeby nikt więcej już nie zachorował. Już nawet nie chodzi mi o pieniądze, które idą jak woda, dobrze, że mogą się przydać. Najniebezpieczniejsza jest utrata sił życiowych i niepewność związana z przyszłością. Jesteśmy mocno osłabieni, ledwo stoimy na nogach.

\section{Wtorek, 23 czerwca 1942}

Od soboty tato jest znowu w szpitalu. Jest tak słaby, że nie jest w stanie nawet ruszyć głową. Tyfus nie odpuszcza. Oprócz tego, że sama choroba trwa długo, osłabienie, które wywołuje, jest niezwykle poważne. Nie podejrzewaliśmy nawet, że jest aż tak chory. Dwa tygodnie był nieprzytomny. Słyszy bardzo słabo, nie lepiej z pamięcią. Lekarz ma nadzieję, że wkrótce wyzdrowieje. Ta choroba kosztowała nas majątek, ale dobrze, że przynajmniej trud nie poszedł na marne. Do tej pory nie wiedziałam, 
że tyfus jest w stanie zniszczyć aż tak szybko zupełnie zdrowy organizm. Jest pełnia lata, ale pogoda jesienna. Wieje, pada, jest chłodno. Daleko do upałów, których oczekiwaliśmy! Dzień już się nie wydłuża, wręcz przeciwnie, zbliżamy się do jesieni. Co będzie teraz? Nie wiemy. Ciągle przychodzą wiadomości o zmarłych, dorosłych i dzieciach, śmierć nie wybiera. Nie mam nawet o czym pisać. Nie mam słów, żeby wyrazić to, co czuję. Jestem pełna tęsknoty, bólu i złości! Jak wyrazić to słowami? Słowa są puste. Wszystko jest niczym, a pośrodku niczego krążą wszystkie moje myśli. Trudno mi powiedzieć, o czym konkretnie myślę, bo wiecznie myślę o niczym. Wszystko kręci się z zawrotną prędkością wokół wspomnień, które dziś już nic nie znaczą. [...]

\section{Piątek, 26 czerwca 1942}

[...] Żydzi i Ukraińcy mogą wychodzić na ulicę jedynie między szóstą a dziewiątą rano ${ }^{21}$. W niedzielę cały dzień, w piątek do godziny dwunastej, w środę i sobotę od czternastej do szesnastej, wtedy można iść na kąpiel. Mamy nadzieję, że wkrótce to rozporządzenie przestanie obowiązywać, ale na razie żandarmeria traktuje je niezwykle poważnie. Powietrze jest gęste, przesiąknięte strachem. Mówi się, że żandarmi mają rozkaz zastrzelić tych, którzy nie będą przestrzegać rozporządzenia. Po prostu, dla przykładu. To smutne, smutniejsze nawet niż to, co było do tej pory. Nie spacerowałam ostatnio zbyt wiele, ale sama świadomość, że mogłam, wiele mi dawała. Teraz muszę wstawać o szóstej, żeby iść po wodę na resztę dnia, a od dziewiątej rano do dziewiątej wieczorem zawsze siedzę w domu i nudzę się. Upadam na duchu. Fizycznie czuję się dość dobrze, ale duchowo? Nie mam przyjaciól, nie mam z kim porozmawiać, nad czym pracować, czego czytać. Mój intelekt każdego dnia zanika. Towarzyszą mi ataki nerwowe, prawdziwe napady płaczu, a każdego dnia jest gorzej. Teraz do tego wszystkiego pojawił się zakaz opuszczania domów. Nie chcę już nic robić. Najchętniej tylko bym spała. Są dni, w których chciałabym umrzeć z takim zapałem, z jakim kiedyś chciałam studiować medycynę. Są też dni, w których chciałabym przeżyć i zobaczyć koniec wojny. Żyć tak pięknie, jak żyłam kiedyś. Śmierć wydaje się lepsza. Towarzyszy jej spokój i ład. Nie ma w niej łez. [...]

${ }^{21}$ Warunki życia Żydów w Transnistrii były określane rozporządzeniami wydawanymi w poszczególnych gettach. Zasady funkcjonowania się zmieniały. Opuszczanie getta było dozwolone każdorazowo w innych godzinach i na różnych zasadach. 


\section{Sobota, 4 lipca 1942}

Już lipiec. To oznacza, że minęło dziewięć miesięcy, od kiedy jesteśmy daleko od domu, a końca nie widać. Takie wahania temperatur, jak te na stepie, są rzadkie. Mimo że powinno być już ciepło, jest chłodno i wietrznie. Wszystko na opak. Rozporządzenia są coraz bardziej upokarzające: mówi się, że getto będzie jeszcze bardziej ograniczone. Wszyscy, którzy mieszkają na Fabrycznej, będą zakwaterowani w dzielnicy żydowskiej. To oznacza większe niebezpieczeństwo. Ściśnięci ludzie, jeden na drugim, nerwy, bród, a w rezultacie choroby i epidemia gotowa. Nie wystarcza, że tylu do dziś zginęło, że setki proszą o jałmużnę, a inni poszczą więcej, niż jedzą, byle tylko nie żebrać. Nie wystarcza im to. Chcą zabić nas wszystkich! Zabić bezradnych Żydów, nic prostszego. Opowiada się straszne rzeczy o Żydach zamordowanych w ukraińskich wsiach i miastach. Nie mieści mi się w głowie, że cywilizowany dwudziesty wiek pozwala na podobny horror. Quo vadis? Udręka pierwszych chrześcijan, a potem dręczenie i torturowanie tych zniewolonych przez egipskich sąsiadów - nic nie ma porównania z teraźniejszością. Matki i ojcowie mordowani na oczach własnych dzieci czy, odwrotnie, dzieci rzucane żywe do grobów, w których spoczywają ich martwi rodzice. A świat milczy, nie jest w stanie przeciwstawić się jednemu człowiekowi, złemu geniuszowi, który go tyranizuje i prowadzi do walki z grupą bezsilnych Żydów. [...]

\section{Wtorek, 15 lipca 1942}

Wiem, że wszystko, co piszę, nie ma najmniejszego sensu. Nikt tego nie przeczyta. Nawet ja, jeśli przeżyję, zapiski rzucę w ogień. Jak zresztą wszystko, co będzie mi przypominać o przeklętym czasie spędzonym w Dżurynie. Mimo to piszę. [...]

\section{Sobota, 20 marca 1943}

Dlaczego nie pisałam od pięciu miesięcy? Dlaczego, skoro tyle razy chciałam pisać? Co mnie zatrzymywało przed zwierzeniem się, wyspowiadaniem tutaj, w moim dzienniku? Jak bardzo potrzebowałam ciebie, drogi powierniku! Jak trudno dać się porwać myślom, zachęcić rękę do pisania, nabrać rozpędu... Podjąć tę malutką decyzję, wykonać zdecydowany ruch, który obudzi mnie z letargu. Ile rzeczy się wydarzyło przez ten czas! Codziennie mogłabym zapełniać cały zeszyt wydarzeniami być może nieznaczącymi, ale jakże ważnymi dla nas. Każdego dnia w tym minionym czasie mogłabym pisać dużo, ale do tej pory wszystkie wydarzenia i ich 
następstwa są podobne do tego, co zdarzyło się rok temu. Któż by pomyślał, że już rok minął, a my wciąż trwamy, żyjemy tu, znosimy zimę, ciężką zimę, żyjemy i chcemy żyć mimo całego tego cierpienia. Uzupełnienie niewypowiedzianego i niezapisanego jest w tym momencie niemożliwe. Byłam bardzo chora, miałam żółtaczkę, wysoką gorączkę. Przez sześć tygodni. Codziennie stres i nerwy o nic. Ostatnio za to chora była mama. Cierpiała na ataki pęcherzyka żółciowego. Tym wszystkim żyliśmy na co dzień. Dziś, po tylu miesiącach milczenia, czuję ogromną potrzebę pisania, szukania odpowiedzi na pytanie, dlaczego okrutny los wygnał nas na ten kraniec świata. Tym właśnie dla mnie jest Dżuryn. Końcem świata. Zostaliśmy przeklęci, bez nadziei, skazani na tortury. Tyle tylko, że dręczone są nasze dusze, nie ciała, co jest znacznie gorsze. Za jakie grzechy pokutujemy? Za jakie przewinienia? Niepewność, w której żyjemy, jest bardziej przytłaczająca niż jakikolwiek wyrok śmierci. Dziś, kolejny raz, trudno powiedzieć już który, pojawiła się plotka, że wracamy do domu. Pewna jestem, że to informacja bez pokrycia. Pożądane przez każdego kłamstwo. Bardziej prawdopodobnym jest, że niedługo usłyszymy o tragicznych wydarzeniach z obozu czy z frontu. Mimo to szczypta nadziei sprawia, że wewnątrz uśmiecham się. Uśmiecham się przez łzy. Człowieku, nie daj się zwodzić mirażom! Półtora roku już żyjemy w nędzy. Przy życiu trzyma nas jedynie nadzieja, że kiedyś wrócimy do domu. Na razie jednak wszystko to kłamstwa sklecone z naszych pragnień. [...]

\section{Niedziela, 10 października 1943}

Wczoraj było święto Jom Kipur ${ }^{22}$, ważny dzień dla Żydów. Prawie każdy pościł. Jedni przez fanatyzm, innych skłoniła skrucha, niektórzy ze strachu. To ciekawe, jaka atmosfera panuje w świąteczny dzień. Przypomina mi to Rosz ha-Szana ${ }^{23}$. Ludzie przedwcześnie zgarbieni, przytłoczeni brzemieniem czasów, pośpiesznie zmierzali do improwizowanej synagogi na odmawianie modlitwy Kol Nidre ${ }^{24}$. Wielki korytarz, przestronna izba odnowiona świątynia Dżuryna. Żydzi stworzyli szil25 na tyle, na ile warunki na to pozwalały. Lampami ze stodoły, świeczkami z wosku i kagankiem

${ }^{22}$ Jom Kipur - jedno z najważniejszych, najbardziej uroczystych religijnych świąt żydowskich o charakterze pokutnym. [przyp. oryginalny]

${ }^{23}$ Rosz ha-Szana - judaistyczne święto Nowego Roku, pierwszy dzień kalendarza żydowskiego.

${ }^{24}$ Kol Nidre - modlitwa żydowska unieważniająca przysięgi religijne, odmawiana przed wieczorem Jom Kipur. [przyp. oryginalny]

${ }_{25} \mathrm{Szil} / \mathrm{szul}$ (jid.) - miejsce modlitwy. [przyp. oryginalny] 
oświetlili miejsce modlitwy. Ich wiara jest tak wielka, że nic nie może im jej odebrać. Ani ludzie, ani czasy. Mimo wstrząsających wydarzeń ubiegłego tygodnia nikt nie zrezygnował z modlitwy. Wręcz przeciwnie, modlą się z większym zapałem, płomieniem, z większą nadzieją. Prawdopodobnie jeszcze wiele cierpień ich czeka, ale modlą się, biją w piersi, czekają. Mają nadzieję i nikt nie jest w stanie im jej odebrać. To cudowny naród, który - mimo że potrafi rozpoznać grzechy - to i tak zawsze je popełnia. Ma tyle woli życia. Nie stracił jej do tej pory i myślę, że nawet te czasy tego nie zmienią. Zmarło wielu i wielu jeszcze zginie. Ci, którzy pozostaną, wspominać będą zmarłych i marzyć o życiu w wolności. Nie chcę o tym zapomnieć, dlatego też zanotowałam wszystkie nieszczęścia i trwogę ostatniej soboty.

Jak już wspominałam wcześniej, przygotowywałam się wtedy do wyjścia do teatru. Czasem bywa tak, że w godzinę dzieje się więcej niż przez cały rok. Po południu Sisi zauważyła, że dużo ludzi krąży po naszej ulicy, więc od razu wysłaliśmy mamę do miasta, żeby dowiedziała się, czy są jakieś nowe wieści. Na początku wszystko wydawało się zwyczajne. Później okazało się, że wszystkie głowy rodzin, mężczyźni lub kobiety, muszą złożyć podpis w Komitecie, przed szefem Żandarmerii, i zobowiązać się, że nie opuszczą getta pod karą śmierci. Wszyscy się przestraszyli, więc przywódcy różnych grup, policjanci i doktor Rosentrauch, przewodniczący getta, obiecali, że postarają się przekonać ludzi do stawienia się. Do nas, ponieważ mieszkamy daleko, nie przyszedł nikt. Mama wróciła i zawołała tatę, ale nie pozwoliliśmy mu iść. Skoro nas nie wezwali, to znaczy, że nie musi iść. Serce podpowiadało mi, że to i tak nie skończy się dobrze, i niestety miałam rację.

Po tym, jak ludzie zebrali się przy jednym stole, ułożono listy, po czym, pod lufami karabinów, zabrano kobiety i dzieci do domów, a mężczyzn do obozów pracy niedaleko Odessy. Płacze biednych kobiet wznosiły się ku niebu, a łzy płynęły strumieniami. Być może łaska niebios odwróci nieszczęścia od tych, którzy bez litości rozproszeni zostali po Mohylowie, Oczakowie $^{26}$, Trihati ${ }^{27}$ i Bóg wie gdzie jeszcze. Jedni wykupili się pieniędzmi. Inni skorzystali z protekcji. Jeszcze inni ocaleli dzięki własnej odwadze, ale wielu wpadło w diabolicznie zastawione sidła. Kolejne dwa dni również

${ }^{26}$ Oczaków (rum. Oceacov) - miasto w obwodzie mikołajowskim na Ukrainie. W czasie okupacji rumuńskiej funkcjonował tam obóz pracy.

27 Trihati (rum. Trihati) - obóz pracy przymusowej przy rzece Boh. W czasie okupacji rumuńskiej Żydzi zostali tam oddelegowani do budowy mostu. 
były straszne. Nie wiedzieliśmy, na czym stoimy, więc pochowaliśmy się wszyscy po kątach. Później dowiedzieliśmy się, jaka była przyczyna tych zawirowań. Okazało się, że aresztowani zostali przywódcy grup w rejonie, w którym kontrola medyczna wykazała nieprawidłowości, i mówi się, że zostali wzięci do obozu pracy w Oczakowie.

Po raz kolejny ludzie z naszego otoczenia zostali zniewoleni. Dobrzy, szlachetni, zawsze skorzy do pomocy innym. Nemesis, bogini zemsty, znalazła sposób, aby wyrównać z nimi rachunki. Za co? Przecież nie zrobili niczego złego, wręcz przeciwnie. Kto to może wiedzieć? To były dni pełne niepokoju, żyliśmy w wielkim strachu. Mimo to nie straciliśmy nadziei, zaczęliśmy nawet wierzyć w plotki o repatriacji. Biedny, gnębiony naród żydowski! Tak pomysłowy w tworzeniu kłamstw płynących z pragnień niespełnionych przez bezlitosnego Boga zemsty.

Wybór i przekład z rumuńskiego Monika Borzęcka monika.borzecka@vp.pl

\section{Źródło archiwalne}

Archiwum Uniwersytetu Jagiellońskiego: Borzęcka Monika, Zapomniany Holokaust. Transnistria w dzienniku Miriam Korber-Bercovici: przekład i analiza, Kraków 2020, maszynopis pracy magisterskiej przygotowanej na Wydziale Historycznym Uniwersytetu Jagiellońskiego.

\section{Źródło opublikowane}

Korber-Bercovici Miriam, Jurnal de ghetou, red. Doina Jela, wstęp Alexandru Florian, wyd. Curtea Veche oraz Institutul Național pentru Studierea Holocaustului din România „Elie Wiesel”, Bukareszt 2017. 